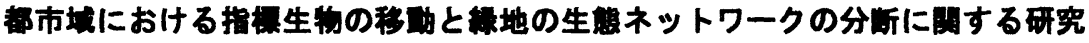

Habitat Fragmentation for Raccoon Dog Caused by Land Use of Transportation in Urban Ecological Networks

\author{
後藤 忍* 盛岡 通** 藤田 壮*** \\ Shinobu GOTO*, Tohru MORIOKA** and Tsuyoshi FUJITA***
}

\begin{abstract}
ABSTRUCT: Habitat fragmentation caused by land use of transportation in urban ecological networks is discussed in this paper. A model that describes the potential of movement probability for selected species was developed and ecological network characteristics were estimated from the conceptual model of network structure in favor of that specie. The authors selected raccoon dog Nyctereutes procyonoides viverrimus as an ecological network indicator, analyzed the distribution data in Ikeda and Kawachinagano city, Osaka prefecture. The results from the case study indicate the followings: 1) the potential of movement probability was not so significant factor for the distribution data compared with urban land use around the casualty points, 2) a large number of recorded raccoon dogs mainly died from traffic accidents at the intersection of the main motorways that run across the network between the woodland patches, 3) the construction of ecological corridor at these intersections is able to reduce the casualties maximally 40 percent. These results contribute to develop the planning concept and system for the effective ecological networks.
\end{abstract}

KEYWORDS: Ecological Networks, Habitat Fragmentation, Landscape Planning, Raccoon Dog

\section{1. 研究の业量と目的}

開発による動植物の生息地の分断化・孤立化を防ぎ，生態系の水平的なつながりを回復させて生物多様性 の保全を図る計画概念は「生態（系）ネットワーク， ecological network）」と呼ばれ，生物の持続可能性や 多様性を高めるための核となる概念として注目され，それを実現するための計画や政策がドイツ・オランダ など欧州を中心として実現されている（Jongman(1995) ${ }^{1}$ ， 日置 $\left.(1999)^{2}\right)^{2}$. わが国でも近年は，生息地として 確保すべき面積や生息地間の距離など定量的な基準を提示する研究がなされてきているが（例えば守山 $(1991)^{3}$, 加藤・一ノ瀬(1993) 、小菅ら $\left.(1997)^{5}\right)$ ， モデルを用いた生態ネットワーク特性の評価や生態的回廊 の設置による効果の推定など，都市域の緑地計画に対する指針を提示している研究例はまだ少ない。

筆者らは、生態ネットワークの構造モデルを設定し，指標種の生息・移動特性に基づく定量的な基準によ って郊外開発地の緑地分布における生態ネットワーク特性を評価するシステムを提示したが6、指標種の分 布情報や分散を表すモデルを用いた生態ネットワーク特性の分析は課題として残された.以上から本研究は, 都市域における指標種の移動を表すモデルを構筑するとともに，分布情報を分析して各地点での移動要因を 明らかにすることにより，都市レベルでの生態ネットワークの形成指針を導くことを目的とする.

\section{2. 研究の桻蚂み}

\section{1 研究のフロー}

本研究の全体の枠組みと分析のフローを図 1 に示す。対象地域の環境情報と指標種の生態情報を用いて,

* 大阪大学大学院環境工学専攻 Ph.D. Candidate, Dept. of Environmental Eng., Osaka Univ.

** 大阪大学大学院教授 工学研究科環境工学専攻 Professor, Dept. of Environmental Eng., Osaka Univ.

****大阪大学大学院助教授 工学研究科環境工学専攻 Associate Professor, Dept. of Environmental Eng, Osaka Univ. 
大きく次の 3 つの視点から分 析を行う．1)指標種の分布特性 を明らかにして，2)生態ネット ワークと緑地間の移動の阻害要 因との関係を分析し，3)土地利 用変化のケースを設定して, 生 態ネットワーク特性の変化を評 価する. すなわち，第一に指標 種の分布地点での移動の起こり やすさを表すモデルを構筑する とともに, 各分布地点の周辺土 地利用割合を算出して, 回収地 点の生態的・環境的特徵を明ら かにする. 第二に, 分析(1)では 十分に評価できない緑地の生態 ネットワーク特性について，指 標種の分散距離を設定してネッ トワークされた緑地を描出する

とともに，それらの緑地間を幹線

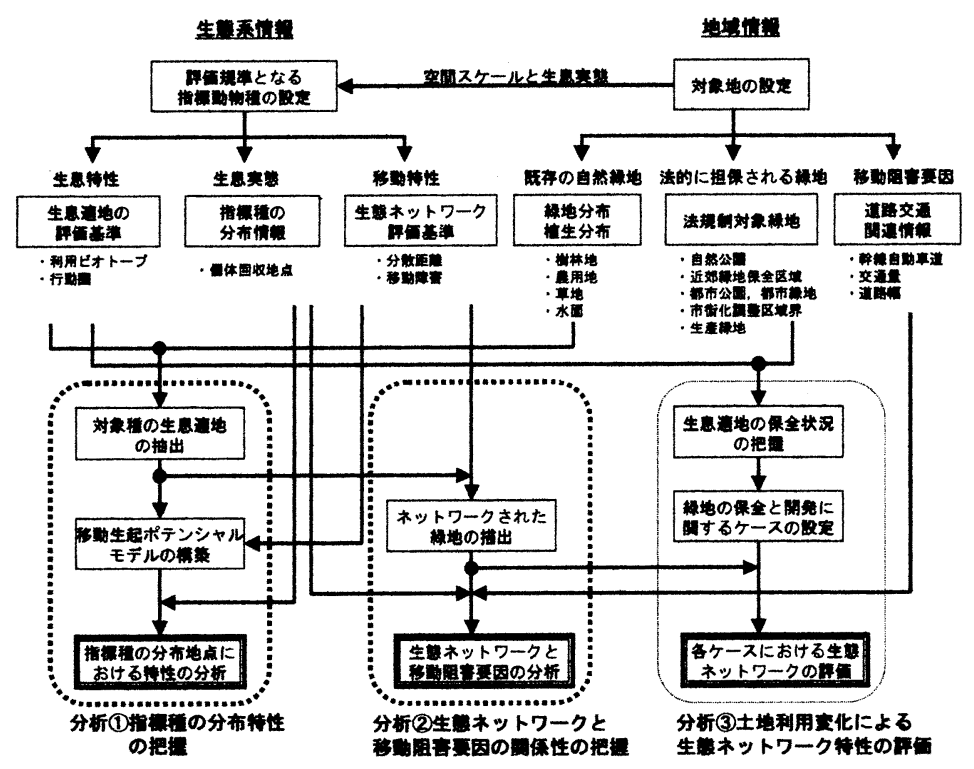

図 1 研究のフロー 緑地政策における指針を導くために, 土地利用の変化について開発が進む場合と緑地が保全される場合でケ 一スを設定し, 各ケースでの生態ネットワーク特性の変化を評価する. このうち, 本研究では分析1および (2)について論じる. なお, 分析(3)については別報7で論じる予定であるので参照されたい.

\section{2 指㮩としてのホンドタヌキ}

本研究では, 都市域における緑地の生態ネットワークを評価する上で指標 となる種としてホンドタヌキNycterentes procyonoides viverrimus（以下タヌキ）を選定 した。指標種の選定については盛岡ら(1998) $)^{6}$ の論文を参照されたい.タヌキの生息 基淮について, 行動圈に関する文献整理（今泉(1994) $)^{8}$, 福江(1991) ${ }^{9}$ など）により, 樹林地パッチ（地形図での広菄・針葉樹林）の規模に応じて表1のように設定した.

\section{表 1 タヌキの生息理境}

\begin{tabular}{|c|c|}
\hline 梦柇地 & 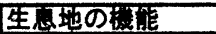 \\
\hline $\begin{array}{l}\text { 天゚゚ッチ } \\
\text { (30ha以上) }\end{array}$ & 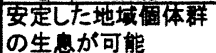 \\
\hline $\begin{array}{l}\text { 中パツチ } \\
\text { (3〜30hด) }\end{array}$ & 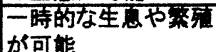 \\
\hline 尔パッチ & 操期地や踏み石E才 \\
\hline (3ha未細) & 1トープとして \\
\hline
\end{tabular}
タヌキの分布に関する情報については，交通事故等によって死亡し自治体に回収された地点の分布デ一タを用いた. その理由として, タヌキの移動を示す都市スケールでの情報であること, 周辺の土地利用やライフスタイルとの相関 が確認されていること10,11,12, などがあげられる. 一方, デメリットとしては, 安全に移動する個体は把握できないこ と, 人の目に触れにくい場所でのデータがないこと，などがあげられ，利用の際に留意する必要がある.

タヌキの環境選択に関する先行研究では, 対象地をメッシュに区切って樹林地の割合（樹林地率）を求め, それを

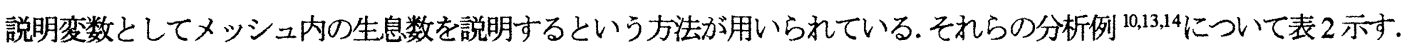
野島(1987) $)^{13}$ では，樹林地率 $20 \%$ 以上でほとんどで生息か確認されている他，山本ら $(1995)^{10}$ でも樹林地率が $10 \%$ 以上で 生息率は $100 \%$ となっており，樹林 地率と生息数に相関があることが確 認されている. また，本研究と同様 に回収個体を扱った山本らの分析で は，樹林地率が低いメッシュで事故 率が高くなる傾向にあることも報告 されており，非樹林性の土地利用の

表 2 メッシュを用いたタヌキの生悤と樹林地率に関する研究例

\begin{tabular}{|c|c|c|c|c|}
\hline Ext? & のンフールド & xッシ2 & 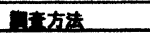 & 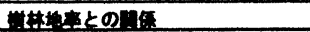 \\
\hline 山本ら(1995) & 川酶市 & $1.5 \times 2.0 \mathrm{~km}$ & 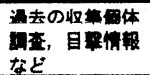 & 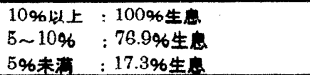 \\
\hline 動禹(1987) & 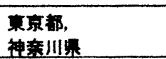 & $5.7 \times 4.7 \mathrm{~km}$ & $\begin{array}{l}\text { ア月き取り, } \\
\text { アンケート }\end{array}$ & 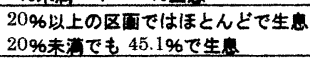 \\
\hline $\begin{array}{l}\text { 池田 - 小霌 } \\
(1980)\end{array}$ & 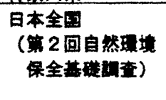 & $1.0 \times 1.0 \mathrm{~km}$ & $\begin{array}{l}\text { 閊を取り, } \\
\text { アンケート }\end{array}$ & 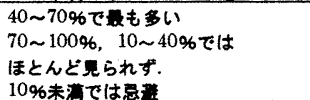 \\
\hline
\end{tabular}


割合が事故率に影響を与えることが示唆されている.

これらの研究ではメッシュの大きさは数 $\mathrm{km} の$ 幅で設定されている．行政資料との整合性などの理 由からこのサイズが用いられているが，1 メッシュ が数 $\mathrm{km}^{2}$ の大きさでは, 平均の行動圈が約 30ha と されるタヌキの移動を分析するのは適当でない，そ のこともあってか，これらの先行研究では移動を表 すモデルを扱った分析は行われていない，そこで本 研究は, メッシュではなく個々の地点ごとに土地利 用割合を算出して分析を行う.

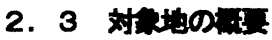

分析対象地は, 事前の電話調査およびアンケートで適地 と判断した, 大阪府下の池田市および河内長野市を選定し た. 調査内容については後藤ら(1998) $)^{15}$ を参照されたい. 池 田市は，回収個体データの保存分が最も多かった市であり、 河内長野市恃大阪府下で一年当たりの回収数が最も多かっ た市である。両市の諸元を表 3, 回収地点の分布を図 2,3 に示す. 池田市は人口集中地区が市域の 50\%を占める市で あり，市街地部分にはほとんど緑地は残されていない，タ ヌキの生息地としては五月山公園とそれに連なる樹林地が 保全されており, 回収地点はそれらの樹林地の近くにある 幹線道路沿いに多く分布している。一方，河内長野市は樹 林地が 70\%近くを占める土地利用であり, 面積は池田市の 約 5 倍である. 人口集中地区の面積は池田市と同程度であ る. 市街地にはパッチ状に残された樹林地が点在しており, 回収地点もその樹林地の近くに分布している. 分析に用い るタヌキの個体回収地点のデータは, 池田市が平成 6〜9 年分 55 件のうち場所が特定できた 38 件 (70\%)，河内長 野市は平成 10 年分 78 件中 32 件 (41\%) である.

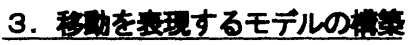

\section{1 分析の视点}

野生生物の交通事故は，1）環境，2)生物，3）交通の 3 つに大別される要素の相互作用の結果であるとされる16. 同様に，個体回収地点の分布も，1）移動の起こりやすさ の要因，2)生物の生態特性の要因，3）死亡率を高める要 因，の 3 つによって決まるものと考えられる.これらの 要素の中で計画的にコントロールできるのは 1)と 3)であ り, 本研究ではこの二つの視点から回収地点の分析を行 う.1)については，生息地となる緑地からの移動の起こ りやすさを表現するモデルを構筑し，各地点における「移
表 3 池田・河内長野両市の諸元

\begin{tabular}{|c|c|c|}
\hline & 㱙画市 & 洄丙是这年 \\
\hline 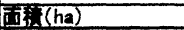 & 2211 & 10961 \\
\hline 人口 & 104292 & 117082 \\
\hline 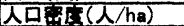 & 47.2 & 10.7 \\
\hline 土地莉南(ha) DID & $1100(50 \%)$ & $1130(10 \%)$ \\
\hline 船市公日 & $196.09(9 \%)$ & $95.55(196)$ \\
\hline & 152. $55(7 \%)$ & $295.6(3 \%)$ \\
\hline 民栾林 & $555(25 \%)$ & $7328(67 \%)$ \\
\hline 王地利用データ & 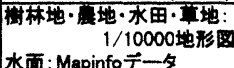 & 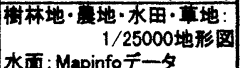 \\
\hline $\begin{array}{r}\text { タヌキ回收体效 } \\
\text { 高効プロット数 }\end{array}$ & 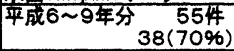 & 平成 10 年分 $\begin{array}{c}78 \text { 珄 } \\
32(41 \%)\end{array}$ \\
\hline
\end{tabular}

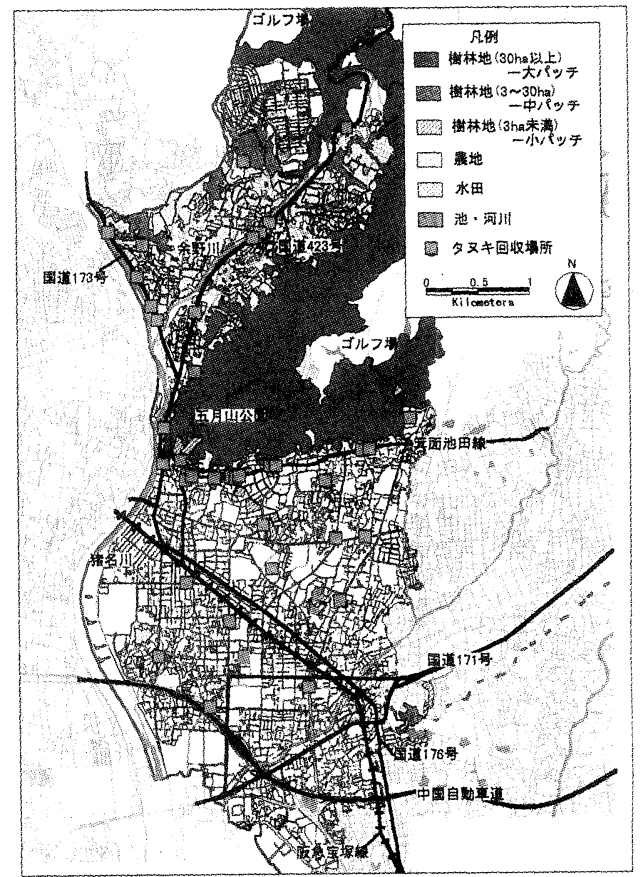

図2 池田市でのタヌキ個体回収地点の分布

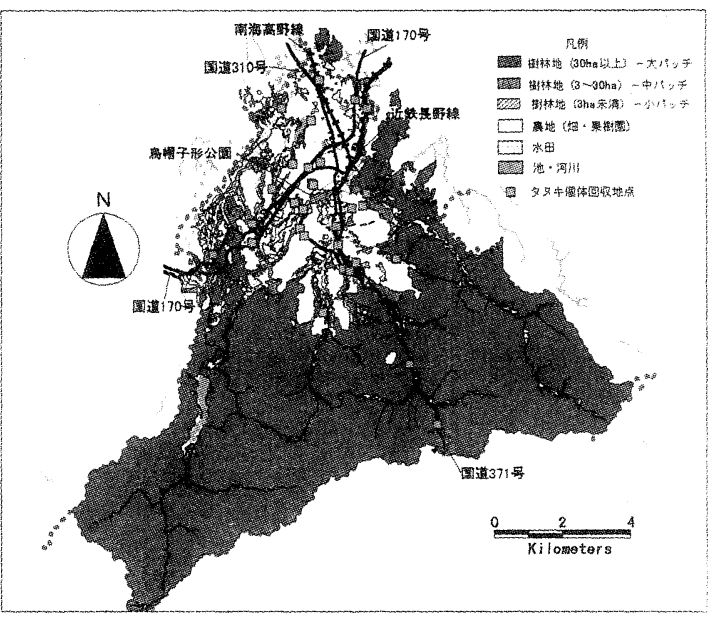

図3 河内長野市でのタヌキ個体回収地点の分布 
動生起ポテンシャル」として算出する．3）に相当するものとしては，2．2で述べたように回収地点の「周辺土地利用 割合」を指標として取り上げる．樹林地などの自然的土地利用の割合が少なく，道路や施設用地などの人工的土地利 用割合が多くなるほど，その場所を移動するタヌキの死亡率が高くなると考えられるからである.

\section{2 相するモデの理}

移動の起こりやすさを表現するモデルの構築にあたり，先行研究で用いられているモデルの整理を行う. 保全生態 学などの分野で用いられている, 生物の生息空間に関する地理情報と生息情報を用いたモデル分析の中で, 特に移動 と分散のモデル化に注目して整理したのが表 4である.この表から得られる知見として，次の点があげられる.

1)パッチからの移動個体の生起頻度を表す式として, Possingham and Davies(1995) ${ }^{17}$ や Hanski and Thomas(1994) ${ }^{18}$, Hansiki(1994) ${ }^{19}$ のモデルで指数関数が使われており, 生起頻度の距離减衰を表す式として妥当であると考えられる.

2)Hanski and Thomas で仮定されている，移入・移出がパッチの大きさや個体群のサイズに無関係であるとする点は, パッチの大きさにばらつきがあるときは成立しないとされており，本研究の対象地のようにパッチのサイズに幅があ る場合には，移入・移出はパッチの大きさに関係があると仮定することができる.

3)Possingham and

Davies の ALEX は,

主としてほ乳類を対

象としたモデル構造

であるため, 本研究

で扱うタヌキを指標

種としたモデル構筑

に反映できると考え

られる.

4)時間変数を入れて絶 滅予測を行うことが 望ましいが, 本研究 のように十分な時系 列データがない場合 は困難である.

これらの知見は, 次 節でのモデル構築に

表 4 先行研究における生物の移勤を表すモデル例

\begin{tabular}{|c|c|c|c|c|c|}
\hline モデル月直 & 研党音／モデル名 & モデルの榑端 & 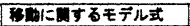 & 用いられているら地 & 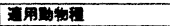 \\
\hline $\begin{array}{l}\text { 人ロ的シミュレ } \\
\text {-ションモデル } \\
\text { Demographic } \\
\text { gimulation model }\end{array}$ & $\begin{array}{l}\text { Lamberson, } R \text {, McK } \\
\text { elvey, } R \text {. and Barry } \\
R(1992)\end{array}$ & 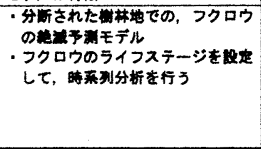 & 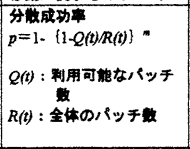 & 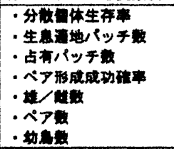 & 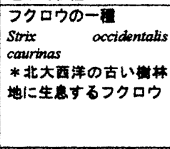 \\
\hline $\begin{array}{l}\text { SPlinin 代モデル } \\
\text { Spatially structured } \\
\text { population model }\end{array}$ & $\begin{array}{|ll|}\text { Possigham, H. P. } \\
\text { and Davies, I. } \\
(1995), & \\
\text { /ALEX } & \\
\text { (analysis } & \text { of } \\
\text { likelihood } & \text { of } \\
\text { extinction) } & \end{array}$ & 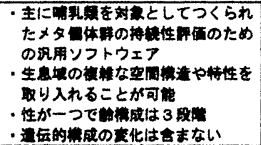 & 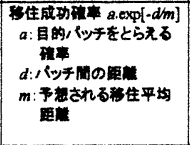 & 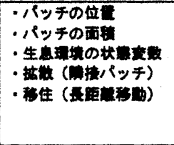 & 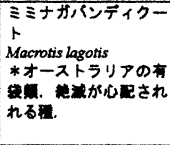 \\
\hline \multirow[t]{2}{*}{ 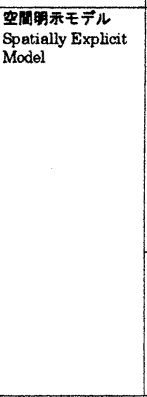 } & $\begin{array}{l}\text { Hanski, I. and } \\
\text { Thomas, C.D. } \\
\text { (1994) }\end{array}$ & 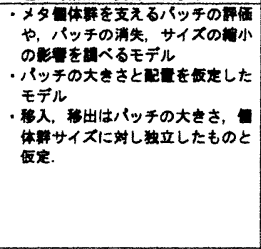 & 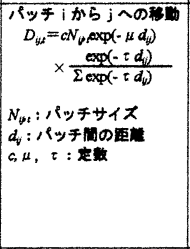 & 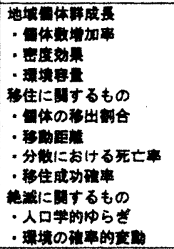 & 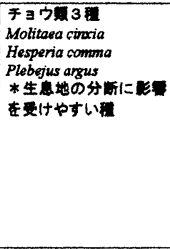 \\
\hline & Hanski, I.(1994) & 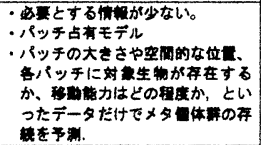 & 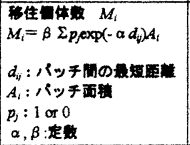 & 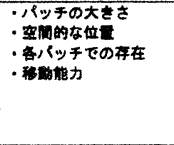 & 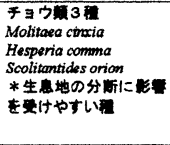 \\
\hline
\end{tabular}

おいて反映させる.

\section{3 移勘の起こりやすを表すモデル}

前節でのモデルの整理，およひ回収地点の分布状況に基づき，タヌキの移動の起こりやすさを表現するモデルを構筑 する. 回収地点の特徵の一つとして, 生息地である緑地から離れるほど数が少なくなることが明らかになっており ${ }^{15}$, この距離减衰を表現するものとして指数関数を採用し，次の3つのステージからなるモデルの構造を仮定する（図 4）.

（1）生息数ポテンシャルモデル

各パッチに生息するタヌキの最大生息数を推定するモデルである. パッチからの移動発生個体の基礎となる数を算 出すモデルであり, 次式で表現されるものとする.

$$
N_{i}=n A_{i} R
$$

ただし, $N_{i}$ : 最大生息可能数, $n: 1$ 行動圈あたりの生息数, $A_{i}$ : パッチ $i$ の面積, $R:$ 最小の行動圈面積である. 


\section{（2）移动個体発生モデル}

生息地からの移動個体の発生量を表すモデルである.(1)式 で求めた生息数ポテンシャルに, 生息地の形状に基づく放出 性を乗じることで求まるものとする. 形状による放出性 $E_{i}$ は, パッチ辺縁部の割合が大きいほどパッチからの発生個体が多 くなると考えられることから, 複雑性を表す次式で表現する.

$$
E_{i}=l_{i} / 2 \pi r_{i} \text { または } l_{i} / A_{i}
$$

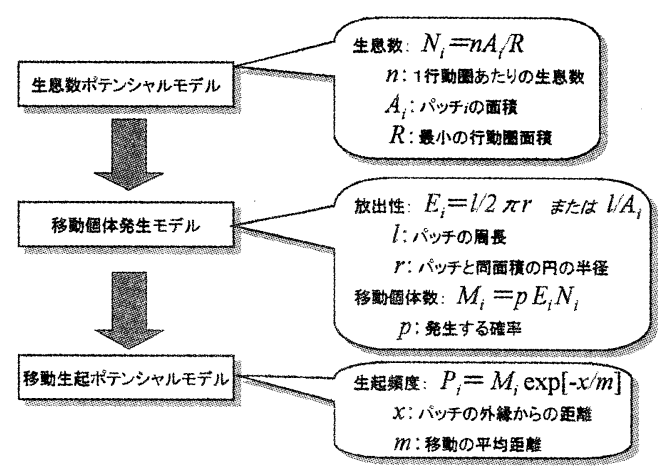

図 4 移動を表すモデルの檄造

ここで, $l_{i}$ はバッチの周長, $r_{i}$ はパッチと同面積の円の半径で ある. 通常, 形状の複雑さを表す変数としては $l / A_{i}$ が用いら れるが，ここでは無次元の係数である前者を採用する.

これに移動個体が起こる割合 $p$ を乗じることで移動個体数 $M_{i}$ をらわすことができる. すなわち，

と表現される.

$$
M_{i}=p E_{i} N_{i}
$$

\section{（3）移功生起ポテンシャルモデル}

タヌキの各回収地点での移動の起こりやすさを表現するモデルであり, 前述したように指数関数を用いて表現する. すなわち, 移動の生起ポテンシャル $P_{i}$ は, 次式により表現されるものとする.

$$
P_{i}=M_{i} \exp [-x / m]
$$

ここで, $x:$ パッチの外緣からの距離, $m:$ 移動の平均距離である. 個体回収地点デ一タでは, 個々の地点から最短の 距離にあるパッチの外縁までの距離を $x$ として分析を行う.

\section{4 各地点での周辺土地利用垥}

各回収地点の環境的特徴を表す指標として, 各地点の周辺 $100 \mathrm{~m}$ 内の土地利用割合を算出する. $100 \mathrm{~m}$ という数値は, タヌキの行動圈として最小のレベルである $3 \mathrm{ha}$ の円の半径に相当する距離であり, タヌキの行動が影響を受ける土地利 用の範囲を表現するのに適当な大きさと考えて設定した. 土地利用の種類は, 地形図から入力した「樹林地」「農用 地」と Mapinfo データの「水面」，およびそれら以外の土地利用である「道路・施設用地」の 4 つであり，それぞれの $100 \mathrm{~m}$ 円に占める比率を求める.

移動生起ポテンシャルを求めるのに用いる変 数と, 回収地点周辺の土地利用の概念図を示し たのが図 5 となる.この図のように，各回収地 点における生息地からの移動の起こりやすさと, 地点周辺における樹林地率や道路・施設用地率 との関係を分析する.

\section{4. 池田市およひ河内最而でのーススタディ}

\section{1 柏牲蛙テンシャルの推定}

以上の枠組みを用いて，対象地における各回収地点 の移動生起ポテンシャルと周辺土地利用割合の算出 を行った.

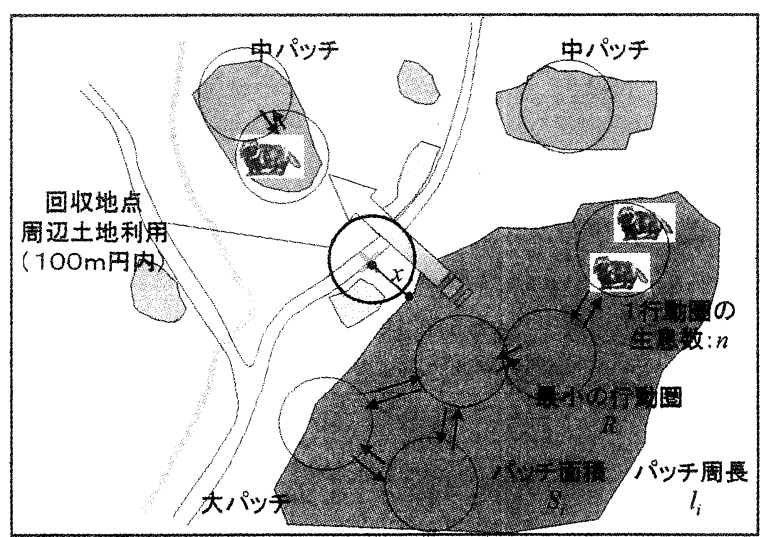

図 5 移動生起ポテンシャルと周辺土地利用の概念図 
移動生起ポテンシャルの推定では, 式中の $p, R, n$ の3つの数について, 先行研究をもとにあらかじめ次のように 数值を設定して算出した.

$\begin{cases}p=0.1 & (\text { Lamkester(1991) })^{20} \text { のモデルでの割合と同值) } \\ R=3 \mathrm{ha} & \left(\text { 今泉 }(1994)^{8}, \text { 横浜市(1993) }\right)^{21} \text { などを参考に最小の行動圈と設定) } \\ n=2 & \left(\mathrm{k} \operatorname{keda}(1985)^{22} \text { での密度を参照して設定) }\right.\end{cases}$

また, $m$ については各分布地点から最短の距離にある中または大パッチまでの平均距離を用いることとし, 算出した 結果, 池田市では $350 \mathrm{~m}$, 河内長野市では $220 \mathrm{~m}$ であった. これらの設定から, GIS 上で各変数の值を測定し, 各回 収地点の移動生起ポテンシャルを求めた。池田市および 河内長野市でのポテンシヤルの大きさを地図上に表現し たのがそれぞれ図 6, 図 7 になる. 池田市では, 五月山 の南側の回収地点で比較的ポテンシャルが高くなってい る他, 西側の国道 423 号線治いも, 樹林地加離れてい るわりには高くなっている. 一方, 河内長野市では, 南 部にある大パッチの周辺や市街地の周囲に残された樹林 地の近くでポテンシャルが高くなっている. 市街地部分 では，環境ふれあい公園である烏帽子形公園へと続く斜 面樹林地との間を 371 号線バイパスが通るところなどは 比較的高くなっている.

これら移動生起ポテンシャルの度数分布を表すと図 8 のようになる。両市ともにポテンシャルが小さいほど件 数が多くなっている. このことは, 回収地点の特徴とし て生息地側からの移動の起こりやすさだけではなく, や はり死亡率を高める要因が強く影響していることを表し ていると考えられる.

\section{2 周辺土地利用时合との明}

回収地点の周辺 $100 \mathrm{~m}$ 内の土地利用割合を算出し, 平均值を表したのが図 9 である. 図から明らかな ように，土地利用の構成は池田市・河内長野市と もにほぼ同じであった。両市とも道路・施設用地 率の割合が $80 \%$ 近くを占めており, 回収地点が道 路等の人間活動が活発な場所に分布していること が分かる．また，その他では樹林地率が最も高く なっており, 生息地や餌場, 移動路としての樹林 地が回収地点の周囲にあることが読みとれる。

道路・施設用地率をタヌキの死亡率を高める要 因として捉え, 移動生起ポテンシャルとの関係を 散布図で表現したのが図 10 である. 両市とも移動 生起ポテンシャルが低く, 道路・施設用地率の高 いところに回收地点が多く分布し，ポテンシャル が大きくなるにつれて道路・施設用地率が小さくな

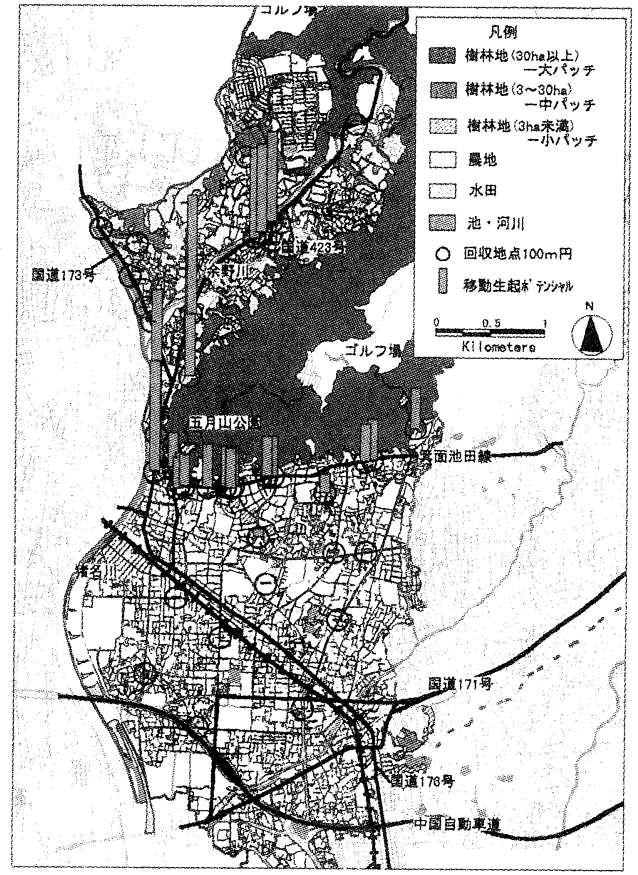

図6 池田市での移動生起ポテンシャルの分布

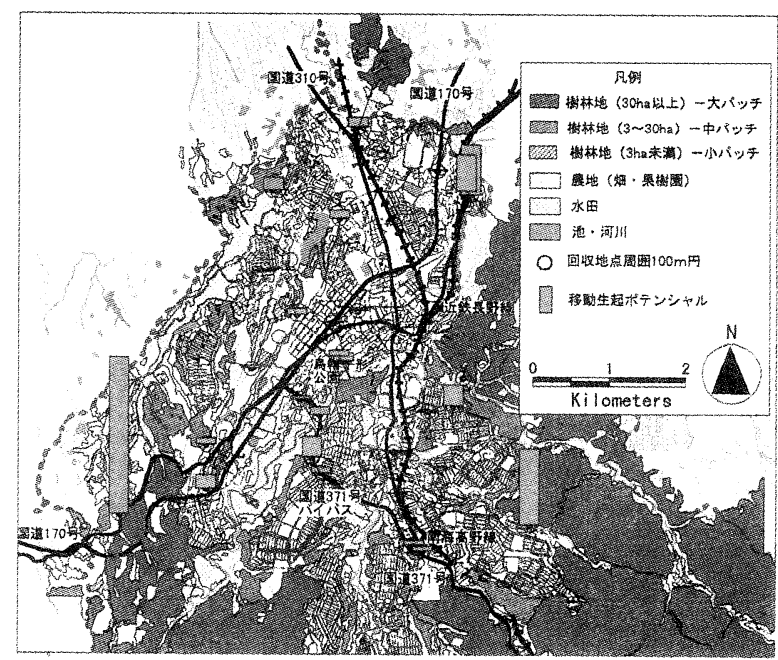

図 7 河内長野市での移動生起ポテンシャルの分布 (市街地部分) 
る傾向を示した. これは，ポテンシャルが高ければ道路・施設用地率が少なくても事故等が起こり, 逆にポテンシャ ルが低くても道路・施設用地率が高ければ同様に事故等が増えることを示していると考えられる.この傾向は池田市 で顕著であり, 直線近似では 5\%有意であった. 一方, 河内長野では移動生起ポテンシャルが低く道路・施設用地率が 高いところに集中しており，池田市ほどの傾向は見られなかった。このことは，池田市では大パッチの緑地から市街 地へしみ出す形で回収地点が分布しているが，河内長野市では大パッチの周囲よりは市街地部に点在する中パッチの 周囲に回収地点が多く分布していることを表すものと考えられる.
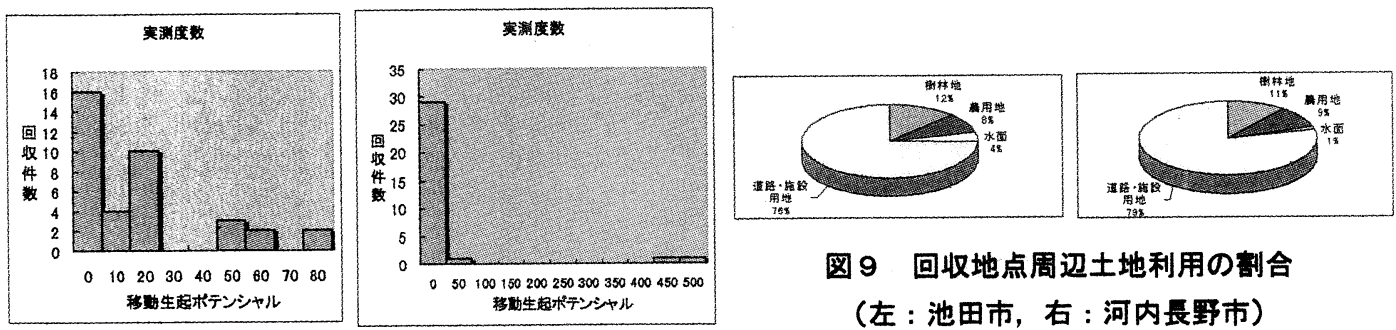

図9回収地点周辺土地利用の割合 (左 : 池田市, 右 : 河内長野市)

图8 移動生起ポテンシャルの度数分布 (左 : 池田市, 右 : 河内長野市)
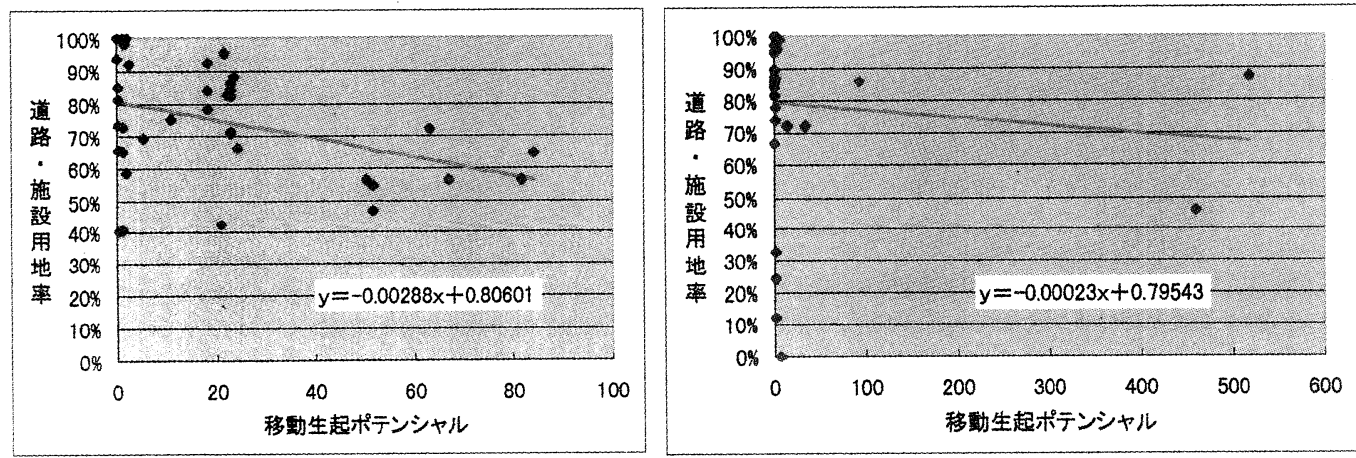

图 10 移勤生起ポテンシャルと道路・施設用地率の関係（左 : 池田市，右 : 河内長野市）

\section{5.道路交による生盛ネットワークの分断}

\section{1 分析の目的と方法}

本章では, 緑地のネットワークと道路交通によるその分断に注目して, 回収数との関係を分析する. 個体 回収地点と施設・道路用地率との相関が高いと判断された前章での結果を踏まえ, タヌキの分散距離内で隣 接する緑地間のネットワークを描出するとともに, 道路交通関連情報を用いて回収数が多い場所の特徵を明 らかにする.このことにより，生態的回廊などの施策を実行すべき地点を特定することも可能になる.

\section{2 分析方法}

分析は次の手順で行う.

(1) ネットワークの描出

盛岡ら(1998) おおよび Linehan et al(1995) ${ }^{23}$ を参考にし，タヌキの分散距離を設定してネットワークされてい る大/中パッチを描出する，分散距離については，谷地森 ${ }^{24}$ の長野県入笠山でのデータ（分散距離 $312 \mathrm{~m} \sim$ $9856 \mathrm{~m}$ ）を参考として, 最小值とほぼ同值の $300 \mathrm{~m}$ と設定した. $300 \mathrm{~m}$ 内に小パッチが介在する場合も, 踏 み石(stepping stone)によるネットワークとして描出する（図 11).

（2）ネットワークされた緑地間での回収地点の带㘣

ネットワークされた緑地間に回収地点が分布している場合，両緑地の中心点を結ぶ軸と各回収地点のなす 
角が鋭角でないものをその緑地間の移動個体と仮定して, 数をカウントする. また，緑地間のネットワークの強さを 表す指標として, Linehan et $\mathrm{al}^{23}$ での空間的相互作用を表 すモデルを参考にし, 重力モデルを基礎とする次式により 緑地間の空間的相互作用を算出する.

$$
G_{i j}=\left(A_{i} / R\right) \times\left(A_{j} / R\right) / D_{i j}{ }^{2}
$$

ただし， $G_{i j}$ : パッチ $i$ とパッチ $j$ 間の空間的相互作用, $A_{i}$ : パッチ $i$ の面䅡, $A_{j}$ : パッチ $j$ の面積, $R$ : 最小の行動圈面 積, $D_{i j}$ : パッチ $i$ と $j$ の中心間の距離である.

\section{（3）道路交通特性との関係性の分析}

ネットワークされた緑地の中心点を結ぶ軸に対し，主 要幹線道路が横断している場所を抽出する. その道路の 特性を表す指標として道路交通量および道路幅をとりあ げ，(2) で求めた回収数および緑地の空間的相互作用 とあわせて，緑地間ごとに整理する。

\section{3 分析枯果}

タヌキの分散距離内でネットワークされた緑地と, 主 要道路における交通量を表したのが図 12，13 である. 池田市では, 緑地のパッチが少なくそれらのネットワー クを分断している道路は存在していない。緑地間の相互 作用範囲内に回収地点が分布しているのは緑地 No.2 と 5 の間だけであり，ここには主要道路は位置していない. このように, 池田市では緑地のネットワークの分断を直 接の要因とする回収個体の発生は少なく, 緑地から市街 地一しみ出す形で移動してきた個体の事故などによる ものが多いと考えられる.一方, 河内長野では, 緑地

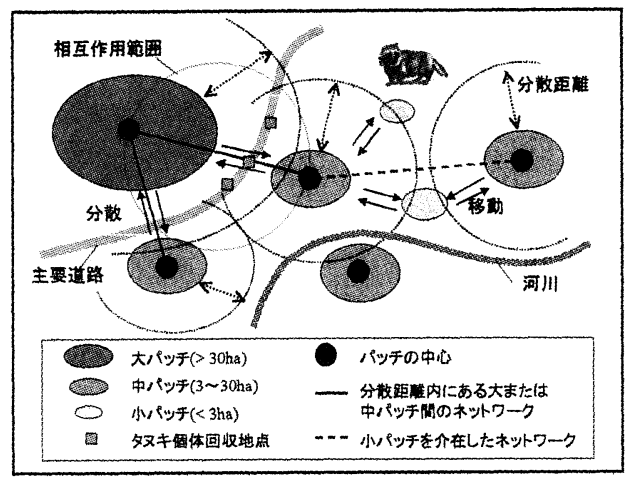

図 11 ネットワーク描出の概念図

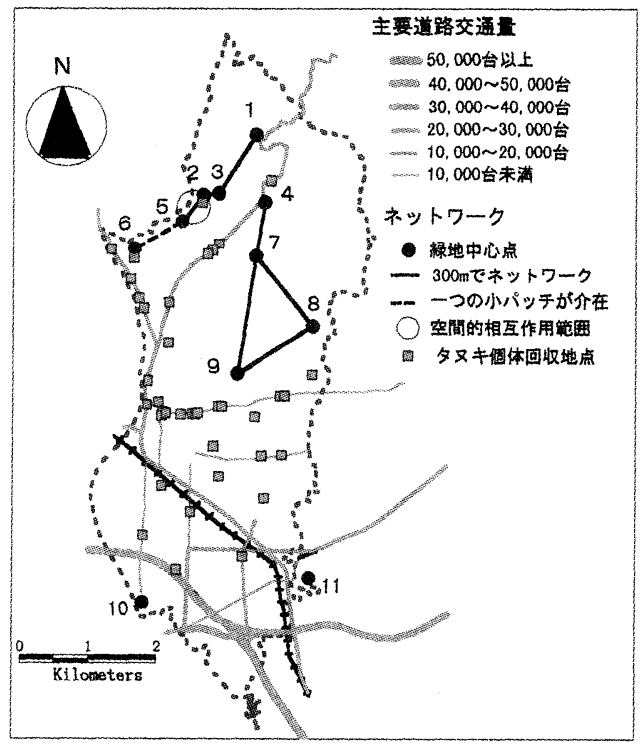

図 12 池田市での生態ネットワークと交通量 間の中心軸を幹線道路が横断するとともに，タヌ キの回収地点が分布している緑地間は $\mathrm{A} \sim \mathrm{F}$ の 11 力所で, 計 18 の個体がそれらの緑地間の相互作 用範囲内に分布していた。これら場所について, 緑地間の空間的相互作用，回収数，および道路幅 と交通量（C，F はデータなし）を整理したのが 表 5 である. 回収数が最大の地点は B と G で 4 件であったが，これらの緑地間を横断する幹線道 路は交通量が 15000 台/半日以上と最も多くなっ ており，タヌキが緑地間を移動する上で事故の起 こりやすい構造になっていることが明らかとなっ た.一方，空間的相互作用の大きさと回収数の間 には明確な関係性はみられなかった。この表から，

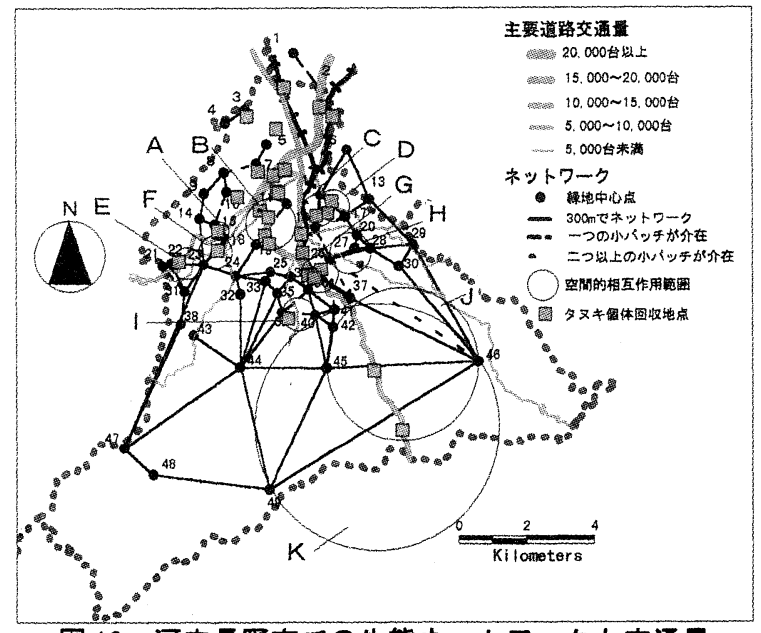

图 13 河内長野市での生態ネットワークと交通量 
道路交通側の特性に基づいて緑地間にタヌキが移動できる 生態的回廊を設置した場合に期待される回収数削减効果も 推定できる. 例えば, 1)交通量 10000 台以上, 2)道路幅 $10 \mathrm{~m}$ 以上，のそれぞれの条件で生態的回廊を緑地間に整備した 場合，1)で約 $31 \%(\mathrm{~B}, \mathrm{G}, \mathrm{J}, \mathrm{K}$ の 10 件)，2)の場合で約 $38 \%$ （B,D,F,G,Iの 12 件）の削减効果が期待できる。これは, 今回場所を特定できなかった地点を含む全件数（78 件） に対しては，それぞれ $13 \% ， 16 \%$ に相当する.

\begin{tabular}{|c|c|c|c|c|}
\hline & 空回的相互作用 & 交逐 (台/半日) & 通路棈(m) & 回収数 \\
\hline $\bar{A}$ & 19.4 & 9096 & 7 & $\overline{1}$ \\
\hline B & 8.1 & 16408 & 15 & 4 \\
\hline C & 3.9 & - & 7 & 1 \\
\hline D & 20.6 & 3129 & 10 & 2 \\
\hline$E$ & 41.3 & 9096 & 7 & 1 \\
\hline$F$ & 48.5 & - & 20 & 1 \\
\hline G & 1.5 & 16408 & 15 & 4 \\
\hline$H$ & 16.2 & 230 & 5 & 1 \\
\hline 1 & 128.7 & 1847 & 10 & 1 \\
\hline J & 6629.1 & 10218 & 7 & 1 \\
\hline $\mathrm{K}$ & 10067.8 & 10218 & 7 & 1 \\
\hline
\end{tabular}

\section{6.本研究のまとめ}

本研究では、都市域における緑地の生態ネットワーク特性を評価するため，指標種としてホンドタヌキを 選定し, 大阪府池田市および河内長野市でのタヌキ個体回収地点のデータをもとに移動の起こりやすさを表 すモデルを構築して, 分布特性を分析した. その結果, 1)回収地点では移動生起ポテンシャルは必ずしも高 くなく, 施設・道路用地率が高くなっていること，2)移動生起ポテンシャルが大きくなるにつれて道路・施設用 地率が小さくなる傾向にあること, などの点が明らかになった。 また, 生態ネットワークの概念モデルを用いて道路 交通情報との関係を分析した結果，3)河内長野市では池田市より分散距離内にある緑地間を幹線道路が横断して いる場所が多く，このことが回収数の増加につながっていると考えられること，4)それらの緑地間に生態的 回廊を整備した場合, 最大で 30〜 40\%の削减効果が期待できること, などの点が導かれた. 回収件数は緑 地の空間的相互作用とはあまり相関がなかったことから，相互作用の大きさに関わらず，分散距離内にある緑地 間を幹線道路が横断している場所では，動物の道路への進入を防ぐとともに安全に移動できるような通路（ボックス カルバート等）を設置するなどの配慮が必要であると言える.このように，本研究で提示したモデルにより，そ れぞれの対象地における生態ネットワークの特性を評価できる可能性が示された。

なお，今後の課題としては，1)ネットワークの状態によるメタ個体群の持続性を評価できるようなモデル を構築すること，2）土地利用変化シナリオを設定して生態ネットワーク計画の効果を予測すること，など があげられる。

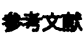

${ }^{1} J$ ongman,R.HG., Nature conservation planning in Europe: developing ecological networks, Landscape and Urban Planming, 32(3), 169-183, 1995

2 日㨁佳之，オランダの生態系ネットワーク，日本造園学会編「ランドスケープエコロジー」，技報堂出版，211-237，1999

3 守山弘，東京近奶の原風量と生物相保全機能，環境情報科学，20-2,27-31，1991

${ }^{4}$ 加藤和弘・一ノ瀬友博, 動物群集保全を意図した璝境評価の視点, 環境掅報科学, 22(4), 62-71, 1993

5 小菅裕・大西博文・小根山裕之, 道路を含めたビオトープネットワーク計画の策定手法に閚する研究, 土木計画学研究・講演集No.20(1), 383-386, 1997

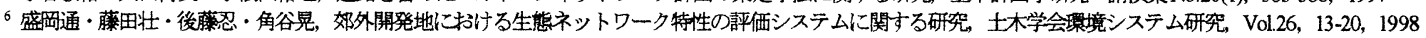

7 後藤忍・盛岡通・藤田壮, 都市域における指標生物の生息特性による緑地の生態学的連続性の評価, 第 13 回珢境情報科学論文投稿中, 1999

8 今泉忠明, 炋狸学入門, 諈談社, 1994

9 福江祐子, 金沢大学楧内におけるホンドタヌキの行動圈利用パターンと Parental care, 平成 3年度金沢大学修士碖文, 1991

10 山本祐治・木下あけみ・東本博之, 川崎市におけけるホンドタヌキNyctereartes procyonoides viverrinus の分布之環境選択, 川崎市青少年科学䗆紀要(6), 83-88, 1995

11 多糜丘陵野外博物捾ためき実行委員会, いまどきの町だぬき，芳栄印刷，20-23，1995

12 木下あけみ・山本祐治, 川崎市域のホンドタヌキ調查 (II), 川崎市青少年科学館紀要(4), 45-50, 1993

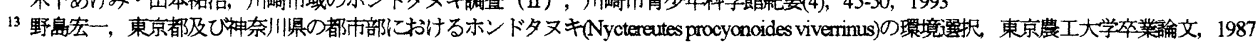

14 池田啓・小野勇一，キツネ・タヌキ・アナグマの分布，第 2 回自然環境保全基磷调查動物分布調查報告（哺乳類），(惧)日本野生生物研究センター，121-158， 1980

15 後藤忍・盛滆通・藤田壮，市街地における生態ネットワーク特性の評価システムに関する調查研究，土木学会環境システム研究，Vol.26，605-610，1998

16 大泰司紀之・井部真理子・增田泰, 野生動物の交通事故対策-エコロード事始め一, 北海道大学谈書刊行会, 1998

${ }_{17}^{17}$ Possigham, H. P. and Davies, I., ALEX: A model for the viability analysis of spatially structured populations, Biol. Cons., 73, 143-150, 1995

${ }^{18}$ Hanski, L and Thomas,C.D., Metapopulation dynamics and conservation: a spatially explicit model applied to butterflies, Biological Conservation 68, 167-180, 1994

${ }^{19}$ Hanski, I., A practical model of metapopulation dynamics, Joumal of Animal Ecology 63, 151-162, 1994

${ }^{20}$ Lankester, $\mathrm{K}$ et al, Management perspectives for populations of the Eurasian badger (meles meles) in a fragmented landscape, Joumal of Applied Ecology 28, $561-573,1991$

21 横兵市, ヨコハマ・エコアップマニュアル, 横浜市, 1993

${ }^{22}$ Hiroshi Ikeda, Regime Alimentaire et Domaine Vital du Chien Viverrin au Japon, Rev. Ecol, vol.40, 1985

${ }^{23}$ Linehan, J. et al, Greenway planning: developing ecological network approach, Landscape and Urban Planning, 33, 179-193, 1995

24 谷地森秀二，野生ホンドタヌキにおける家族関係の推定と家族を構成する個体群の行動変化，日本大学博士論文
} 